\title{
Attempting Discussion of Commercial Banks' Innovative Strategy-Promoting the Intermediary Business
}

\author{
Yang Bai $^{1}$, Ziru Sun ${ }^{2}$ \\ ${ }^{1}$ Xijing University, Xi'an Shanxi, 710123,China \\ ${ }^{2}$ Yan'an University, Yan'an Shanxi, 716000,China
}

Keyword: Commercial Bank, Intermediary Business, Innovative Strategy.

\begin{abstract}
The major businesses of Chinese commercial banks include the intermediary business, assets business and liability business. Currently, Chinese commercial banks have emphasized on developing the assets and liability business. As one basic business of Chinese commercial banks, such a situation has greatly blocked the full development. Consequently, commercial banks must innovate the intermediary business and fully improve all kinds of problems and deficiencies, so as to offer better service for the development of commercial banks.
\end{abstract}

\section{Introduction}

Under the background of economic globalization, the marketalization process of bank rate has also been consistently accelerated. To realize the leap-forward development, commercial banks must innovate the intermediary business and realize the growth points of new profits by innovation. During recent years, Chinese commercial banks have consistently attached more importance to the intermediary business. However, compared to western commercial banks, there are great gaps no matter in the aspect of quality or scale.

\section{Major Problems of Chinese Commercial Banks' Intermediary Business}

\section{Extremely Lack of Professionals and Advanced Technologies}

No matter in any industry of any country, professional technology is the major power promoting the development. However, while developing the intermediary business, Chinese commercial banks have utterly lacked professionals, which is the major factor hindering the development of commercial banks' intermediary business. Intermediary business of commercial banks is characterized by fast information change, high technical content and wide range of specialty. Therefore, to realize the innovation and development of intermediary business, it must be supported by a lot of developed scientific technologies, composite and high-level talents. However, in view of the current development of Chinese commercial banks' intermediary business, it has been extremely short of information management system, technical equipment and professional technicians, and also far lagged behind. The intermediary business has quite low service level and working efficiency, but also consumes a lot of time, which cannot satisfy the modern clients' requirements of being highly efficient and convenient. Besides, the backward technologies make the collection and feedback of information to be confronted by serious problem of postponement. The senior management of banks cannot monitor or process all kinds of emergencies in time or efficiently based on the information, which greatly reduces the working efficiency. 


\section{Chinese Commercial Banks' Intermediary Business Possessing Quite Small Operation Scale}

\section{and Quite Low Profits}

During recent years, although Chinese commercial banks have attached more and more importance to the intermediary business, and also made certain development in the aspect, however, there is a large gap compared to other developed countries. Commercial banks of some western developed countries have especially focused on the development of their intermediary business. Profit brought by the intermediary business usually occupies half of the total profits. However, profit of Chinese intermediary business usually cannot occupy $1 / 10$ of the commercial bank's profit. In addition, species and structures of Chinese commercial banks' intermediary business are quite unreasonable. The operation scope is also quite simple. Although there are hundreds of intermediary businesses in Chinese commercial banks, they are mostly concentrated on settlement, charging, paying and foreign exchange settlement and sale, which are products with quite low added value and technical contents. Although commercial banks have devoted great material resources and manpower, the profit margin is still quite low.

\section{Unsounded Charging Mechanism of Intermediary Business}

Intermediary businesses of Chinese commercial banks usually refer to payroll and utilities expense. Under normal circumstances, these businesses are given to clients as a gift, so as to keep clients better, which usually do not charge any intermediary fee. For a long time, the entrusting party and users have get accustomed to and enjoyed the convenience brought to their work and life. They also take the free service for granted. However, Chinese commercial banks have consistently developed the intermediary business. There are more and more varieties, wider and wider scope, thus technological resources, manpower, network and sites have also been consistently increased. The operation cost of the intermediary business has also constantly increased. In addition, commercial banks have constantly lowered the rates. If commercial banks still do not charge the intermediary business, it will generate great influence on the profit margin in future.

\section{Quite Poor Development Environment of Intermediary Business, Unordered Market Competition}

Compared to other countries, the intermediary business of Chinese commercial banks has been started relatively late, which are extremely unsounded in the aspect of system, law, market and policy. Intermediary business products of Chinese commercial banks are mostly the mixture of banking service, insurance and security. However, operation system of Chinese commercial banks is usually separate operation, which brings great obstacles to the innovations of the intermediary business. The intermediary market of our country has no sound laws or regulations to guide or regulate the development and innovations, which results in many orderly malicious competitions in the intermediary market of the commercial banks.

\section{Lack of Efficient Control over All Risks}

Chinese commercial banks have great problems in the governance structure. There are no clear management responsibilities of various bank risks, the management philosophy is inaccurate and there are in accurate risk-taking subject. Due to the lack of commercial banks' risk management constraint mechanism, the management personnel cannot actually undertake the authoritative or independent risk management responsibility. Therefore, risk management personnel do not attach much importance to the legal risk, market risk or credit risk. Especially the credit risk, it merely rests on the layer of estimating, recognizing and digesting various non-performing loans. There is no sound credit risk management and control system.

\section{Imperfect Management System and Operational Mechanism of Intermediary Business}


While developing the intermediary business, Chinese commercial banks have no scientific operational or management system, thus they cannot carry out unified management or planning during the process of development. while carrying out the management, due to the lack of consistent and unified decision and business policy, and also the effectiveness of business development, it has generated a lot of influence on the innovation and development of the intermediary business. Moreover, although some commercial banks set up the intermediary business department at different levels, due to the deviation of understandings, there are no specific inspection methods or mechanisms to inspect the development situation of intermediary business. Fatherly, it cannot form a sound or efficient supervision and incentive mechanism.

\section{Chinese Commercial Banks' Major Countermeasures to Realize the Innovation and Development of Intermediary Business}

\section{Improving the Employment Mechanism of Commercial Banks, Optimizing the Talent Structure}

Chinese commercial banks usually pay attention to the degree while selecting the talents, which cannot make necessary evaluation on the professional technologies or ability level. To realize the innovation and development of the intermediary business, Chinese commercial banks need to correctly understand the innovative ability and learning potentials of the business personnel, so as to select high-standard and high-quality talents with degree and innovative consciousness as the reserve force for developing the intermediary business. They have to carry out systematic and long-term training about the practice ability, theoretical knowledge and professional skills. Commercial banks mainly aim at training the comprehensively modern talents who thoroughly understand theoretical knowledge and financial practice ability; master the international financial knowledge and get familiar with the computer technology; understand all kinds of financial policies and laws and regulations, with the innovative abilities. Chinese commercial banks not only have to emphasize on the training of working personnel, but also vigorously introduce external excellent talents who dare to exploit the market, possess wide scope of knowledge and professional qualification, so as to pave the way for the innovation and development of the intermediary business. Meanwhile, commercial banks still need to strengthen the training of original workers. By the step-by-step and hierarchical training method, it can indeed improve the comprehensive qualities of business personnel; while selecting talents, it needs to evaluate and select talents by entrusting universities and colleges.

\section{Introducing Advanced Technologies, Improving Service Level and Working Efficiency}

The intermediary businesses of Chinese commercial banks refer to modern financial service businesses centering on the service quality, electronic intelligence and scientific technology. To realize innovations and development, it needs to pay attention to introduce advanced technologies, so as to constantly improve the service level and working efficiency. Development of the intermediary businesses needs to be supported by the computer and Internet technology and soft development technology. Therefore, Chinese commercial banks need to increase the investments and strengthen the supporting force, constantly introduce advanced foreign technologies, so as to increased the added value of the intermediary business and obtain quite big development and progress.

\section{Positively Making Reference to the Development Experience of Developed Countries}

By referring to the experience of commercial banks in developed countries, it cannot only efficiently cut down the development costs of all products, but also efficiently shorten the innovative circle of products. First of all, it should expand the service scope of intermediary business, positively open personal check and personal remittance businesses, increase the foreign exchange settlement and sale by developing international settlement, so as to increase the account service, bank loans and trade financing. Meanwhile, large credit associations and banks can undertake the business of bill of 
exchange. Secondly, it should also positively expand the scope of acting businesses, such as acting the accounting, insurance, justice, custody, issuance and financing.

\section{Standardizing the Marketing Order of the Intermediary Business, Reinforcing the Ability to Resist Risks}

In order to realize the innovations and development of the intermediary businesses, Chinese commercial banks need to set up a quite perfect system of business supervision, charge instruction and industrial regulation firstly, and then it should make a comprehensive explanation of all operational procedures, so as to guarantee the intermediary business personnel to have laws to abide. Meanwhile, it should strengthen the labor division management of the whole staff. By specific labor division, it can specify responsibilities that everyone should undertake, so as to constantly improve their working initiative and enthusiasm.

\section{The Management Personnel of Commercial Banks should Positively Change Their Operation Principles.}

To set up a modern operation principle suitable for the market economy system, Chinese commercial banks need to completely transform the state-owned banks' management and operation philosophies under the traditional planned economic system. Secondly, they should strengthen the awareness of market, center on customers and consistently develop themselves and the market advantage of intermediary business by centering on the market demand. Finally, they should strengthen their awareness of profits; take the operation benefits and development qualities of banks as the destination and starting point of the intermediary businesses. In this way, they can develop the intermediary businesses, further to realize the banks' development objective of profit maximization.

\section{Important Reasons Why Chinese Commercial Banks Innovating and Developing the Intermediary Businesses}

\section{Need to Strengthen the International Financial Competitiveness}

With the arrival of the global economic integration, traditional operational modes of commercial banks cannot meet the demands of market any more. Under the fierce competition of both domestic and foreign financial markets, confronted by foreign banks with comprehensive service, advanced operation philosophy and numerous products, Chinese commercial banks need to vigorously develop their intermediary businesses, so as to improve their own comprehensiveness. As long as Chinese commercial banks vigorously develop the intermediary businesses, can they monitor the changes of international financial environment, further to conduct preventions in time. During the process of development, they should positively follow the development situation of the international financial industry, gradually transform the financing function of the intermediary business into the function of service. Meanwhile, they should have more diversified resources of profits, replace the traditional scale-orientation by the value-orientation, set up a concentrated operational mode and constantly integrate all kinds of resource advantages, so as to improve their management service level and operational efficiency.

\section{Satisfying the Demands of Market System Reform}

Chinese commercial banks have gradually completed the joint-stock system reform. By constantly introducing the external strategic investors, they can realize the value maximization of shareholders. Under the guidance of such a management philosophy, in order to rapidly realize the governance structure and construct a modern financial enterprise, Chinese commercial banks need to face the vigorous innovations of business type and scope, positively develop the intermediary businesses. In addition, from the reform of Chinese market economic system, it is an objective requirement for Chinese commercial banks to innovate and develop the intermediary business, further to adapt themselves to the reform of market system. 


\section{Necessities to Adapt Themselves to the Interest Rate Liberalization}

One great achievement of Chinese financial system reform is the interest rate liberalization, which not only places great influence on the operation and management pattern of Chinese financial industry, but also offers a quite good platform for the development of price competition. The competitions from financial market become much fiercer. Shares that all banks occupy in the financial market have also been changed greatly. The profit margins of banks have been constantly cut down. Under such a circumstance, to strengthen their competitiveness and increase their own market shares, commercial banks need to innovate the profit growth point by innovating and developing their intermediary businesses, so as to realize the transformation to non-interest income and the diversified resources of profits, and then constantly increase their comprehensive strength.

\section{Increasingly Accelerated Progress of Financial Liberalization}

Today, with the globalization of economy, the progress of financial liberalization has also been constantly accelerated. Te exchange rate and interest rate have gradually realized the liberalization. The original business restrictions have been gradually cancelled and the financial fields have constantly expanded. The developing countries have also gradually opened their domestic financial markets. Foreign banks can set up their branches in Chinese financial markets to develop their foreign financial businesses. The high liberation of financial market not only requires Chinese commercial banks to constantly improve their operational efficiency, but also to accelerate their development and innovations, so as to constantly meet the demands of financial liberalization.

\section{Conclusion}

With constant development of financial businesses, commercial banks have been confronted by more and more complicated problems and challenges. To efficiently cope with emergencies of the financial market, they must vigorously develop the intermediary businesses. Only by constantly increasing the products of intermediary businesses and expanding the business scope, can they effectively guarantee the profits of commercial banks and strengthen the comprehensive competitiveness.

\section{References}

[1] Yu Rong. Brief Analysis on the Intermediary Businesses of Commercial Banks, Journal of Huainan Industrial Institute (Social Science Edition), 2008(02)

[2] Lu Chunjie. Positively Expanding the Intermediary Business Improving the Competitiveness of Commercial Banks, Journal of Henan Financial Management Cadre Institute, 2009(01)

[3] Zhang Jiming. The Absolute Choice for Commercial Banks to Vigorously Expand the Intermediary Business, Journal of Henan Financial Management Cadre Institute, 2008(01)

[4] Chen Jing, Kan Zhou, Kan Bin. Brief Analysis on the Intermediary Businesses of Commercial Banks, Journal of Chizhou Teachers College, 2009(01)

[5] Lin Gaungyi. Advantages, Difficulties and Countermeasures of Commercial Banks while Developing the Intermediary Businesses, Exploration and Truth-seeking, 2009(08) 
